\title{
Incubation of Cocaine Seeking following Brief Cocaine Experience in Mice Is Enhanced by mGluR1 Blockade
}

\author{
Briac Halbout, ${ }^{*}$ Rick E. Bernardi, ${ }^{*}$ Anita C. Hansson, and Rainer Spanagel \\ ${ }^{1}$ Institute of Psychopharmacology, Central Institute of Mental Health, Medical Faculty Mannheim, University of Heidelberg, 68159 Mannheim, Germany
}

\begin{abstract}
The incubation of cocaine craving describes the time-dependent augmentation of cue-induced cocaine seeking during withdrawal from prolonged cocaine self-administration and requires time-dependent changes in neuroplasticity at the level of glutamatergic synapses in the nucleus accumbens $(\mathrm{NAc})$. In contrast to most studies that use multiple cocaine-cue conditioning sessions, the present study tested mice with limited cocaine experience (i.e., a single conditioning session) in the incubation of cue-mediated cocaine seeking and its associated changes in the glutamate system. Mice that self-administered cocaine during a single session exhibited a time-dependent increase in their response for the drug-associated cue as compared to mice that self-administered saline. This behavior was associated with changes in AMPA and NMDA receptor binding characteristics. Furthermore, Group I metabotropic glutamate receptor (mGluR1) mRNA levels were altered in several brain regions, including the NAc. Because of the pivotal role of mGluR1 in the control of cocaineinduced plasticity, we investigated the role of mGluR1 in the formation of drug cue-mediated cocaine seeking. After prolonged withdrawal, mice in which an mGluR1 antagonist was administered following cocaine self-administration displayed increased cocaine seeking compared to vehicle-treated mice. These results suggest that limited cocaine experience is sufficient to induce neurobiological changes that enable an initially neutral cue to acquire motivational value that increases over time, an effect that likely involves glutamate signaling through mGluR1.
\end{abstract}

Key words: addiction; AMPA and NMDA receptors; cocaine self-administration; drug-seeking; metabotropic glutamate receptors; relapse

\section{Introduction}

In humans, cocaine craving can occur in response to environmental stimuli previously associated with drug use (Ehrman et al., 1992), and is thought to play a critical role in the maintenance of cocaine use and the precipitation of relapse, even after extended periods of abstinence (Gawin, 1991; O'Brien, 1997). In animals, cocaine seeking can be measured by the response to cues previously associated with the self-administration of cocaine (Meil and See, 1996; Sanchis-Segura and Spanagel, 2006; Stephens et al., 2010), which may represent a model of relapse vulnerability in response to cocaine-conditioned stimuli (Epstein et al., 2006). Interestingly, cue-elicited cocaine seeking in rats and mice has been shown to increase progressively during the first 2

\footnotetext{
Received March 12, 2013; revised Nov. 19, 2013; accepted Nov. 27, 2013

Author contributions: B.H., R.E.B., A.C.H., and R.S. designed research; B.H., R.E.B., and A.C.H. performed research; B.H., R.E.B., A.C.H., and R.S. analyzed data; B.H., R.E.B., A.C.H., and R.S. wrote the paper.

This work was supported by the Bundesministerium für Bildung und Forschung (NGFN Plus; FKZ: 01GS08152, see Spanagel et al., 2010), the Deutsche Forschungsgemeinschaft HA 6102/1-1, SFB 636 (B1) and Reinhart-Koselleck Award SP 383/5-1, and the MWK in Baden-Württemberg. We are thankful to Dr. Anton Bespalov for providing A-841720.

${ }^{*}$ B.H. and R.E.B. contributed equally to this work.

The authors declare no competing financial interests.

Correspondence should be addressed to Rainer Spanagel, Institute of Psychopharmacology, Central Institute of Mental Health, Medical Faculty Mannheim, University of Heidelberg, J5, 68159 Mannheim, Germany. E-mail: rainer.spanagel@zi-mannheim.de.

B. Halbout's present address: Department of Microbiology and Molecular Genetics, Inserm U904, University of California, Irvine, CA 92697.

DOI:10.1523/JNEUROSCI.1076-13.2014

Copyright $\odot 2014$ the authors $\quad 0270-6474 / 14 / 341781-10 \$ 15.00 / 0$
}

months of abstinence from drug self-administration (Grimm et al., 2001; Lu et al., 2004; Mead et al., 2007). This phenomenon, referred to as the incubation of cocaine seeking, appears not to be influenced by environmental factors (Thiel et al., 2012), and is consistent with the hypothesis that in humans, craving increases over time and remains high following a prolonged period of abstinence (Gawin and Kleber, 1986). Time-dependent changes in neuroplasticity in several structures of the mesolimbic brain reward system have been demonstrated during cocaine withdrawal and likely mediate the incubation of cocaine seeking (Hollander and Carelli, 2007; Lu et al., 2007, 2009; Conrad et al., 2008; Pickens et al., 2011; Ben-Shahar et al., 2013; Li et al., 2013).

Drug-induced changes in the glutamate system play an important role in synaptic plasticity and underlie some aspects of the "aberrant" learning that drives drug-seeking behavior (Hyman et al., 2006; Lüscher and Malenka, 2011). For instance, withdrawal from both extended cocaine self-administration and passively administered cocaine is associated with enhanced AMPA receptor (AMPAR)-mediated transmission in the nucleus accumbens (NAc; Boudreau and Wolf, 2005; Conrad et al., 2008; McCutcheon et al., 2011a; Wolf and Tseng, 2012). Furthermore, under extended cocaine self-administration, a time-sensitive accumulation of $\mathrm{Ca}^{2+}$-permeable AMPAR (CP-AMPAR) that lacks the GluR2 subunit, which plays an important role in synaptic plasticity, is thought to mediate the time-dependent increase in drug seeking (Conrad et al., 2008; Mameli et al., 2009). It has recently been shown that $\mathrm{CP}-\mathrm{AMPAR}$ accumulation in the NAc 
is under the control of glutamate metabotropic receptor 1 (mGluR1) in the ventral tegmental area (VTA; Bellone and Lüscher, 2006; Mameli et al., 2007, 2009). In addition, it has been demonstrated that mGluR1 also mediates CP-AMPAR accumulation via a direct mechanism in the NAc (McCutcheon et al., $2011 b$ ). These findings suggest two potentially distinct substrates controlling the regulation of CP-AMPAR during cocaine withdrawal.

Most studies examining the mechanisms that underlie incubation of cocaine seeking have assumed that extended cocaine self-administration is a prerequisite for the time-dependent increase in cocaine seeking and associated neuroadaptations. We sought to investigate the consequences of a single session of cocaine self-administration on the development of incubation of cocaine seeking. Furthermore, we hypothesized that mGluR1 dysfunction increases the vulnerability to cocaine-induced plasticity and consequently to cocaine seeking in response to drugassociated stimuli. Therefore, we assessed the consequences of mGluR1 blockade on cocaine seeking following prolonged withdrawal in mice subjected to limited cocaine self-administration.

\section{Materials and Methods}

Animals. Male C57BL/6N mice, 10-12 weeks old at the start of the experiment (Charles River), were single housed and maintained on a $12 \mathrm{~h}$ light/dark cycle (with lights on at 07:00) under controlled temperature $\left(21 \pm 2^{\circ} \mathrm{C}\right)$ and humidity $(50 \pm 5 \%)$ conditions. All experiments took place during the light phase. Throughout the experiment mice received ad libitum access to food. Experiments were conducted in accordance with European Union guidelines on the care and use of laboratory animals and were approved by the local animal care committee (Regierungspräsidium, Karlsruhe, Germany).

Incubation of cocaine seeking (repeated access). The procedures for lever training for food, surgery, and catheter maintenance were as previously described (Mameli et al., 2009). In brief, to familiarize mice with the action of lever pressing, all mice were trained to lever press for $14 \mathrm{mg}$ of sucrose-based food pellets (TestDiet; maximum $141 \mathrm{~h}$ sessions), during which no discrete cues were presented. The implantation of an indwelling catheter in the right jugular vein occurred $24 \mathrm{~h}$ after completion of lever training. Animals were given a minimum of $48 \mathrm{~h}$ recovery before cocaine self-administration sessions began.

Two groups of mice (Day 9 or Day 43; $n=7-8$ ) self-administered cocaine hydrochloride $(0.5 \mathrm{mg} / \mathrm{kg} /$ infusion; Sigma-Aldrich) for eight consecutive sessions (Days 1-8; Fig. 1A). Self-administration sessions lasted $6 \mathrm{~h}$ or were terminated when animals had earned 100 infusions during the first session or 150 infusions during subsequent sessions. During self-administration sessions, responses on the active lever under a fixed ratio 1 (FR1) schedule of reinforcement resulted in a cocaine or physiological saline infusion (US) of $14 \mu \mathrm{l}$ by activation of the pump for $1.2 \mathrm{~s}$. Each drug infusion was associated with the $10 \mathrm{~s}$ presentation of cue lights (CS). A time-out period during which additional presses on the active lever did not lead to further saline or cocaine infusion followed each infusion and lasted $40 \mathrm{~s}$. Mice were tested for cocaine-induced reinstatement either the day following completion of the self-administration phase (Day 9) or following $35 \mathrm{~d}$ of abstinence (Day 43). Testing conditions were similar to those in the self-administration phase, except that responses on the active lever resulted in the presentation of the CS for $5 \mathrm{~s}$ and sessions were $60 \mathrm{~min}$ in duration.

Incubation of cocaine seeking (single exposure). A separate group of mice self-administered cocaine $(0.5 \mathrm{mg} / \mathrm{kg} /$ infusion $)$ during one session of $6 \mathrm{~h}$ or for a maximum of 100 infusions (Day 1; Fig. 1D). Animals were returned to their home cage and distributed into two groups; one group $(n=7)$ was tested for cue-induced cocaine seeking on Day 9, while the other was tested on Day $43(n=8)$. In parallel, control animals selfadministered physiological saline under the same conditions (i.e., a single session of $6 \mathrm{~h})$ and tested either on Day $9(n=6)$ or Day $43(n=7)$.

Incubation of cocaine seeking (single exposure without food training). To determine whether prior food training was responsible for our single session incubation effect, a separate group of mice not previously lever trained using a food pellet reinforcer self-administered cocaine $(0.5 \mathrm{mg} /$ $\mathrm{kg}$ /infusion) during a single $6 \mathrm{~h}$ session or for a maximum of $100 \mathrm{infu}-$ sions (Day 1; Fig. 1D). Animals were returned to their home cage and distributed into two groups; one group was tested for cue-induced cocaine seeking on Day 9 while the other was tested on Day 43. Because of poor compliance without food training during a single session of cocaine self-administration, and the necessity of animals to sufficiently learn the cue-cocaine contingency to effectively express drug-seeking behavior in response to the cue during later testing, animals were excluded from the study if their responding on the active lever was $<70 \%$ of total lever responding (i.e., both inactive and active levers), resulting in $n=7$ and $n=6$ for the Day 9 and 43 groups, respectively.

Cue-induced food seeking. To further determine whether prior food training was responsible for our single session incubation effect, 16 mice were randomly assigned to one of two groups (Day 9 or Day 43; $n=$ 8/group) and underwent the self-administration of food pellets (described above) for 8 consecutive days. Sessions lasted $120 \mathrm{~min}$ and were initiated by the presentation of two levers. Food pellet delivery (US) was contingent upon pressing on the active lever under an FR1 schedule of reinforcement and paired with the $10 \mathrm{~s}$ presentation of a light stimulus (CS) also signaling a time-out period, during which lever presses were not reinforced. For all experiments, presses on the inactive lever were recorded but had no scheduled consequence. The side of the active lever was counterbalanced across subjects and remained constant during the experiment. Mice that failed to adequately acquire the task $(<50 \%$ of presses on the active lever on Day 8 of self-administration) were removed from analysis ( $n=2$; thus, data reflects $n=7$ per group). Mice were given a $1 \mathrm{~h}$ cue-induced, food-seeking test either $24 \mathrm{~h}$ (Day 9) or $35 \mathrm{~d}$ (Day 43) following the last self-administration session. During this session, conditions were identical to those during self-administration except that lever pressing resulted in the CS presentation but no food pellet.

$m$ GluR1 blockade and cocaine seeking following protracted withdrawal. An additional batch of mice self-administered cocaine $(0.5 \mathrm{mg} / \mathrm{kg} / \mathrm{infu}-$ sion) during one session of $6 \mathrm{~h}$, or a maximum of 100 infusions (Day 1 ). Animals were returned to their home cage and distributed into two groups ( $n=9 /$ group) that received daily treatment with the noncompetitive mGluR1 antagonist A-841720 (Abbott; El-Kouhen et al., 2006) at doses of $0 \mathrm{mg} / \mathrm{kg}$ or $10 \mathrm{mg} / \mathrm{kg}$ intraperitoneally for 7 consecutive days (Fig. 6A). In parallel, control animals that self-administered physiological saline under the same conditions (i.e., a single session of $6 \mathrm{~h}$ ) received either A-841720 $(n=7)$ or vehicle treatment $(n=5)$ when returned to their home cage. All mice were subsequently tested for cue-induced cocaine seeking on Day 43. A- 841720 was dissolved in $10 \%$ dimethylsulfoxide and $90 \%$ polyethylene glycol (PEG400). The dose of $10 \mathrm{mg} / \mathrm{kg}$ was chosen based on its effects as demonstrated by El-Kouhen et al. (2006), as well as additional pilot experiments (data not shown).

Tissue preparation for receptor autoradiography and in situ hybridization. Mice were killed by decapitation on Day 9 or Day 43 after a single cocaine or saline self-administration session, immediately following the cue test ( $n=5-8$ /group). It is important to note that only animals that underwent food-mediated lever training before single session cocaine self-administration were used for molecular studies. Brains were quickly removed and flash frozen in isopentane at $-40^{\circ} \mathrm{C}$. The brains were stored at $-80^{\circ} \mathrm{C}$ until further use. For expression studies, reward-related brain regions were chosen based on Noori et al. (2012). Coronal brain sections $(12 \mu \mathrm{m})$ were cut on a cryostat (Leica CM1950; Leica Biosystems) at bregma levels +2.0 to $+1.9 \mathrm{~mm},+1.1$ to $+0.9 \mathrm{~mm},-1.3$ to $-1.6 \mathrm{~mm}$, and -3.1 to $-3.4 \mathrm{~mm}$ according to the brain atlas (Paxinos and Franklin, 2001; Fig. 3) and thaw mounted on either gelatin-coated slides for receptor autoradiography or on SuperFrost Plus slides (Fisher Scientific) for in situ hybridization.

Saturated receptor autoradiography. For $\left[{ }^{3} \mathrm{H}\right]$-AMPA autoradiography, sections were incubated for $3 \times 10 \mathrm{~min}$ at $4^{\circ} \mathrm{C}$ in $50 \mathrm{~mm}$ Tris- $\mathrm{HCl}$ buffer, pH 7.2, $2.5 \mathrm{mM} \mathrm{CaCl}_{2}$. Sections were then transferred into humidified chambers and $800 \mu \mathrm{l}$ of reaction mix was applied to each slide and sections were incubated for $1 \mathrm{~h}$ at $4^{\circ} \mathrm{C}$. Reaction mix contained $20 \mathrm{nM}$ [ ${ }^{3} \mathrm{H}$ ]-AMPA (Sp.Act. $45.8 \mathrm{Ci} / \mathrm{mmol}$; PerkinElmer) prepared in a buffer containing $50 \mathrm{~mm}$ Tris- $\mathrm{HCl}, \mathrm{pH}$ 7.2, $2.5 \mathrm{~mm} \mathrm{CaCl}_{2}$, and $100 \mathrm{~mm}$ potas- 
sium thiocyanate (KSCN; Sigma-Aldrich). Nonspecific binding was measured on adjacent sections with the addition of $100 \mu \mathrm{M}$ quisqualic acid (Tocris Bioscience). For $\left[{ }^{3} \mathrm{H}\right]-\mathrm{MK}-801$ autoradiography, sections were brought up to room temperature, incubated for $2 \times 10 \mathrm{~min}$ at room temperature in $5 \mathrm{~mm}$ Tris- $\mathrm{HCl}$ buffer, $\mathrm{pH} 7.2$, and $2.5 \mathrm{mM} \mathrm{CaCl}_{2}$, and incubated in room temperature for $1 \mathrm{~h}$ in a buffer containing $8 \mathrm{nM}$ [ ${ }^{3} \mathrm{H}$ ]-MK-801 (Sp.Act. $22 \mathrm{Ci} / \mathrm{mmol}$; PerkinElmer), $5 \mathrm{~mm}$ Tris-HCl, $\mathrm{pH}$ 7.2, $5 \mu \mathrm{M}$ L-glutamate, $5 \mu \mathrm{M}$ L-glycine, and $5 \mu \mathrm{M}$ spermidine (SigmaAldrich). Nonspecific binding was determined on adjacent sections, which were incubated with additional $100 \mu \mathrm{M}$ MK-801 (Tocris Bioscience). Incubation of both $\left[{ }^{3} \mathrm{H}\right]$-AMPA and $\left[{ }^{3} \mathrm{H}\right]-\mathrm{MK}-801$ was stopped by washing the sections for $3 \times 2 \mathrm{~s}$ in ice-cold buffer (AMPA: $50 \mathrm{~mm}$ Tris-HCl, pH 7.2, $2.5 \mathrm{~mm} \mathrm{CaCl}_{2}$; NMDA: 5 mM Tris-HCl, pH7.2) and $2 \times 2 \mathrm{~s}$ in ice-cold acetone/glutaraldehyde (100:2.5), followed by a dip in ice-cold deionized water. Sections were dried under a stream of cold air and exposed against FUJI imaging plates (Storage Phosphor Screen BAS-IP TR2025 E Tritium Screen; GE Healthcare Life Sciences) for $10 \mathrm{~d}$ and scanned in a phosphorimager (FUJI BAS-5000 Phosphorimager; GE Healthcare Life Sciences). Densitometric analysis was performed using the MCID program (InterFocus Imaging). Signal density was measured as photostimulable luminescence per $\mathrm{mm}^{2}$, compared against standard curves generated using $[3 \mathrm{H}]$-microscales (GE Healthcare Life Sciences) and data $(\mathrm{nCi} / \mathrm{mg})$ were converted to fmol receptor per milligram protein tissue equivalence. Specific binding was defined as a difference between total and nonspecific binding.

In situ hybridization. For mGluR1 no specific radioactive-labeled antibody is available. Therefore, in vitro labeling of riboprobes using UTPS35 and in situ hybridizations were performed as recently described (Hansson et al., 2006, 2008). The $m G l u R 1$ riboprobe was generated based on gene reference sequence in the PubMed database (http://www.ncbi. nlm.nih.gov/refseq/); $m$ GluR1: Position 2914 bp to 3168 bp on rat cDNA (gene reference number: NM 017011.1) with 95\% sequence homology to corresponding mouse cDNA. After in situ hybridization sections were exposed to phosphorimaging plates (Fuji Storage Phosphor Screen BAS-IP SR2025) for $7 \mathrm{~d}$ and scanned by the phosphorimager. Densitometric analysis was performed using the MCID Image Analysis Software (Imaging Research). Signal density was measured as photostimulable luminescence per $\mathrm{mm}^{2}$, compared against standard curves generated using $\left[{ }^{14} \mathrm{C}\right]$-microscales (GE Healthcare Life Sciences) and data expressed as $\mathrm{nCi} / \mathrm{g}$.

Statistical analysis. All data are expressed as means \pm SEM. For the behavioral experiments, the number of lever presses and infusions were analyzed by repeated measures ANOVA (with Session and Lever as the repeated variable, and Treatment, Group, and/or Drug as the betweensubject variable) followed by post hoc analyses where specified. Receptor binding and mRNA expression studies were statistically compared regionwise by two-way ANOVA followed by Fisher's PLSD test and Bonferroni's correction (Fisher's $p$ value multiplied by the number of analyzed brain regions). Significance was set at $p<0.05$.

\section{Results}

\section{Repeated access to cocaine self-administration promotes the} incubation of cocaine seeking in mice

We first verified that repeated access to cocaine self-administration induced an incubation of cocaine seeking. Lever training for food was similar between the two groups (data not shown), as revealed by the lack of significant difference on both the total number of lever presses during training $\left(t_{(13)}=0.83, p=0.42\right)$ and the total number of sessions required for training $\left(t_{(13)}=\right.$ $0.16, p=0.87)$. Cocaine self-administration was similar between the two groups tested on subsequent Days 9 and 43 (Fig. 1B). A repeated-measures ANOVA on the number of lever presses revealed no initial difference in the propensity to self-administer cocaine (Group $\times$ Session $\times$ Lever, with repeated effect on Session and Lever, $F_{(7,84)}=1.78, p=0.1$; Group $\times$ Lever: $F_{(1,12)}=$ $0.09, p=0.763$; Session $\times$ Lever: $\left.F_{(7,84)}=3.32, p<0.05\right)$. Similarly, there was no difference in the number of infusions earned
(Group $\times$ Session, with repeated effect on Session, $F_{(7,84)}=1.79$, $p=0.1$ ). However, mice tested for cocaine seeking $35 \mathrm{~d}$ after the last session of self-administration (Day 43) exhibited significantly higher active lever presses than mice tested the day immediately following self-administration (Day 9; Fig. $1 C$ ). A factorial ANOVA revealed significant effects of Group $\left(F_{(1,12)}=25.03\right.$, $p<0.05)$ and Lever $\left(F_{(1,12)}=52.05, p<0.05\right)$ as well as a significant Group $\times$ Lever interaction $\left(F_{(1,12)}=33.1, p<0.05\right)$; post hoc analysis confirmed that active lever presses on Day 43 were significantly higher as compared with the Day 9 group $(p<$ $0.05)$, though no difference in inactive lever pressing was seen.

\section{A single session of cocaine self-administration promotes the incubation of cocaine seeking}

We next assessed whether a single session of cocaine selfadministration supported the incubation of cocaine seeking (Fig. $1 D)$. Lever training for food was similar between the different groups (data not shown), as revealed by the lack of significant difference on both the total number of lever presses during training $\left(F_{(3,24)}=1.12, p=0.36\right)$ and the total number of sessions required for training $\left(F_{(3,24)}=0.89, p=0.45\right)$. Following food training, mice exhibited a high level of active lever presses for the self-administration of both cocaine and saline (Fig. 1E). Responding for cocaine and saline was nonetheless significantly different as shown by a two-way ANOVA (Drug $\times$ Lever: $\left.F_{(1,23)}=8.94 ; p<0.05\right)$ and post hoc analysis that revealed significant differences between active and inactive lever presses for the cocaine self-administrating groups only. The difference between saline and cocaine self-administrating groups was further confirmed by an analysis of the number of infusions earned during the $6 \mathrm{~h}$ session. A factorial ANOVA revealed a significant effect of Drug $\left(F_{(1,23)}=7.7, p<0.05\right)$, but no main effect of Group or Group $\times$ Drug interaction $(F s=0.85$ and 2.33 , respectively, $p s>$ $0.05)$. Importantly, these analyses confirm that cocaine selfadministrating groups tested on either Day 9 or Day 43 did not differ in their initial cocaine experience (i.e., similar lever presses, cocaine infusions, and thus US-CS pairings). When tested for cocaine seeking (Fig. $1 F$ ), responses for the cocaine-paired cue was significantly higher in the group tested on Day 43 as compared with the group tested shortly after self-administration ( post hoc analysis that followed factorial ANOVA, Drug $\times$ Group $\times$ Lever: $\left.F_{(1,23)}=6.87, p<0.05\right)$; moreover, incubation of cueinduced responding following a single session of self-administration was specific to a cocaine-paired cue, as mice that self-administered saline showed identical responding regardless of test interval (Day 9 or Day 43; post hoc, $p>0.05$ ).

\section{A single session of cocaine self-administration without food training promotes the incubation of cocaine seeking}

To rule out the possibility that the incubation phenomenon in our single-session cocaine experiment was driven by previous food training experience, we tested cocaine cue responding in animals not previously trained to lever press for a food pellet reinforcer. Mice subsequently tested on Days 9 and 43, intervals consistent with our previous experiments, demonstrated acquisition of cocaine self-administration during a single $6 \mathrm{~h}$ session that did not differ as a function of group assignment. Figure $2 \mathrm{~A}$ shows the active and inactive lever presses during the $6 \mathrm{~h}$ session. A two-way ANOVA (Lever $\times$ Group, with repeated measures on Lever) revealed no significant interaction $(F<1, p=0.98)$ or main effect of Group $(F<1, p=0.39)$, but a significant main effect of Lever $\left(F_{(1,11)}=41.5, p<0.001\right)$, indicating a distinction between the active (reinforced) and inactive (nonreinforced) le- 
A

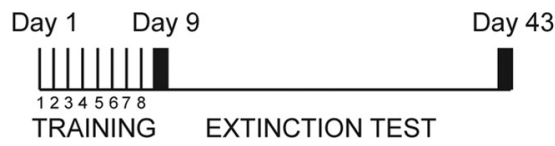

B

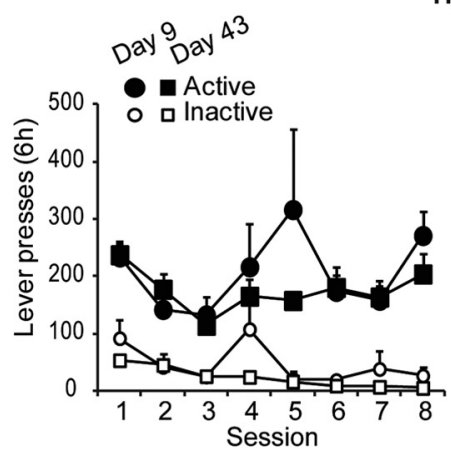

TRAINING

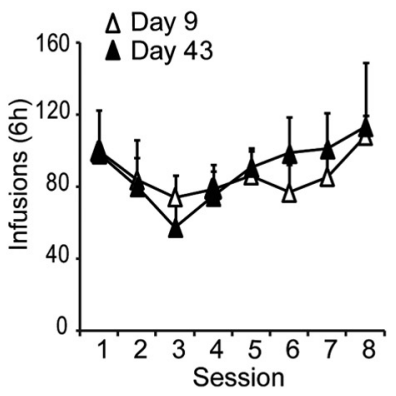

C

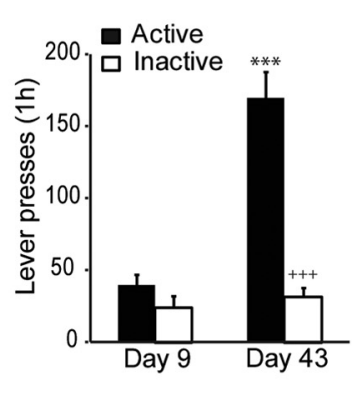

D

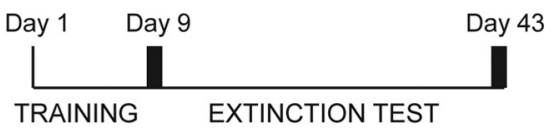

E

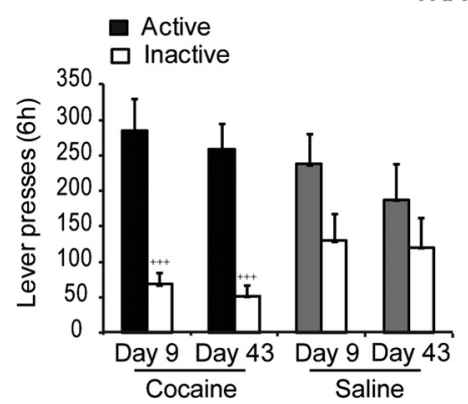

TRAINING

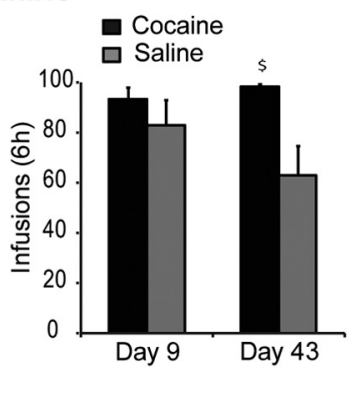

F

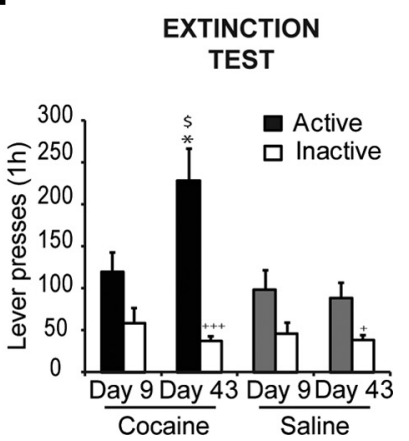

Figure 1. Incubation of cocaine seeking occurs following both extended and a single session of cocaine self-administration. $\boldsymbol{A}$, Schematic diagram of the time course for the incubation of cocaine-seeking experiment. Days 1-8: cocaine self-administration followed by cue-induced cocaine seeking was measured on Days 9 and 43 . $\boldsymbol{B}$, The number of lever presses during cocaine self-administration (TRAINING) does not differ between the groups subsequently tested on Days 9 and 43 ( $n=7-8 /$ group). The number of infusions also did not differ between the mice tested later on Days 9 and 43. C, The number of lever presses during the cocaine-seeking test (EXTINCTION TEST) shows that incubation of cocaine seeking occurs following prolonged self-administration $\left({ }^{++} p<0.001\right.$ vs Active; ${ }^{* * *} p<0.001$ vs Active on Day 9$)$. D, Schematic diagram of the time course for the incubation of cocaine seeking following a single session of cocaine self-administration. Day 1: cocaine self-administration followed by cue-induced cocaine seeking on Days 9 and 43 . $E$, During a single 6 h session, mice displayed a high number of active lever presses for cocaine (black bars, Active lever; white bars; Inactive lever; ${ }^{+++} p<0.001$ vs Active). Lever presses for the cocaine self-administrating groups (TRAINING) subsequently tested on Day 9 ( $n=7$ ) and Day 43 ( $n=$ 8) did not differ significantly. Mice self-administrating saline (TRAINING; $n=6-7 /$ group) displayed a high level of active lever presses (gray bars) that did not differ from inactive lever presses (white bars). Right, Number of cocaine or saline infusions received during the $6 \mathrm{~h}$ session ( $\$ p<0.05$ vs Saline). $\boldsymbol{F}$, Incubation of cocaine seeking occurs following a single session of self-administration (EXTINCTION TEST). The number of active lever presses for the cocaine-associated cue was significantly higher for the group tested on Day 43, as compared with the group tested on Day 9 , and those of groups responding for saline-associated cues $\left({ }^{*} p<0.05\right.$ vs Day $9 ;{ }^{\$} p<0.05$ vs Saline; ${ }^{+++} p<0.001$ vs Active; ${ }^{+} p<0.05$ vs Active). Data are expressed as mean \pm SEM.

vers during the $6 \mathrm{~h}$ trial. Furthermore, there was no difference in the number of cocaine reinforcers earned during the session $(F<$ $1, p=0.38)$. During testing, mice showed a significant difference in responding based on test interval. Figure $2 B$ shows the active and inactive lever presses for each group during the $1 \mathrm{~h}$ test session on Day 9 or Day 43. A two-way ANOVA (Group $\times$ Lever) revealed significant main effects of lever $\left(F_{(1,11)}=58.4, p<\right.$ $0.001)$ and group $\left(F_{(1,11)}=6.5, p<0.05\right)$, and most importantly, a significant Group $\times$ Lever interaction $\left(F_{(1,11)}=6.0, p<0.05\right)$; post hoc analysis confirmed that active lever presses on Day 43 were significantly higher as compared with the Day 9 group $(p<$ $0.05)$, though no difference in inactive lever pressing was seen, indicating the incubation of cue responding following the longer interval period, and discounting prior food training as the cause of our single cocaine session incubation effect.
Food self-administration does not promote the incubation of cue-induced food seeking

To further eliminate prior food-mediated lever training as a potential confound in the cocaine incubation effect, and in an attempt to confirm that the cocaine-cue association mediated this behavior, we tested responding for cues associated with food selfadministration. Mice demonstrated acquisition of the selfadministration of food pellets during $8 \mathrm{~d}$ that did not differ as a function of group assignment (i.e., subsequently tested on Day 9 or 43). Figure $2 C$ shows the active and inactive lever presses over the course of the $8 \mathrm{~d}$. A three-way ANOVA (Session $\times$ Lever $\times$ Group) revealed no significant interactions $(F s<1.5$, ps $>0.05)$ or main effects of Group $(F<1, p=0.76)$ or Session $(F<1.1$, $p=0.37)$. However, there was a main effect of Lever $\left(F_{(1,12)}=\right.$ $16.9, p<0.005)$, indicating that all animals learned to distinguish 
A

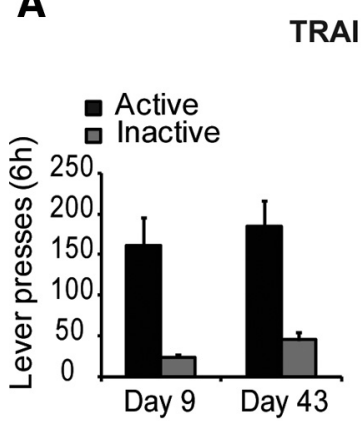

C

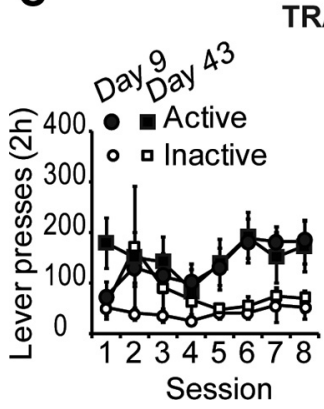

TRAINING

B

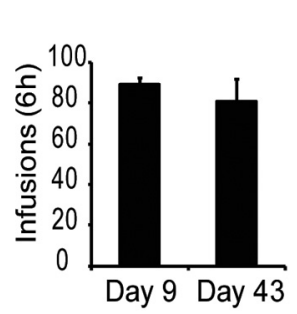

RAINING

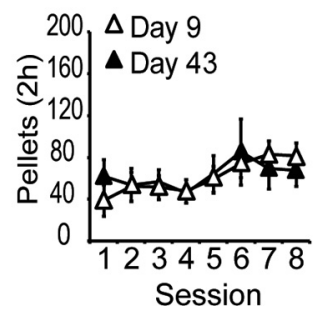

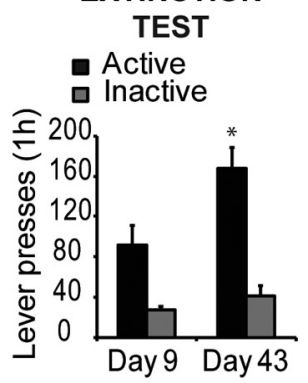

D

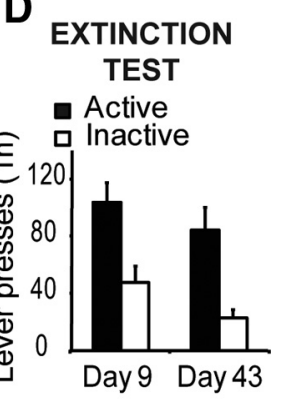

Figure 2. Food training does not account for the incubation of cocaine seeking. $A$, During a single $6 \mathrm{~h}$ session, mice acquired cocaine self-administration without prior food training (TRAINING). Lever presses for the groups subsequently tested on Day 9 and Day 43 did not differ ( $n=6-7 /$ group). Right, Number of cocaine infusions received during the $6 \mathrm{~h}$ session did not differ between the groups. $\boldsymbol{B}$, Incubation of cocaine seeking occurs following a single session of self-administration without previous food training (EXTINCTION TEST). The number of active lever presses for the cocaine-associated cue was significantly higher for the group tested on Day 43 , as compared with the group tested on Day $9\left({ }^{*} p<0.05\right)$ C, Self-administration of food pellets (TRAINING) as shown by the number of lever presses does not differ between the groups tested on Day $9(n=7)$ and Day $43(n=7)$. Number of food pellet reinforcers is similar between the two groups. D, Mice do not display an incubation of cue-induced food seeking (EXTINCTION TEST). Lever presses for the food-associated cue does not differ between the mice tested on Days 9 and 43 . Data are expressed as mean \pm SEM.

between the active (reinforced) and inactive (nonreinforced) levers during the experiment. Furthermore, there was no difference in the number of food pellet earned during the $8 \mathrm{~d}$ experiment. A two-way ANOVA (Group $\times$ Session) revealed no interaction or main effect of Group ( $F s<1$, ps $>0.05$ ). During testing, mice showed no difference in cue responding based on testing day. Figure $2 D$ shows the active and inactive lever presses for each group during the $1 \mathrm{~h}$ test session on Day 9 or Day 43. A two-way ANOVA (Group $\times$ Lever) revealed no significant interaction $(F<1, p=0.74)$ or main effect of $\operatorname{Group}\left(F_{(1,12)}=2.1, p=0.18\right)$, but a main effect of Lever $\left(F_{(1,12)}=50.3, p<0.001\right)$.

\section{A single session of cocaine self-administration is associated} with changes in glutamate receptors expression in the reward system

To investigate the nature of time-dependent molecular changes associated with the incubation of cocaine seeking following a single session of cocaine self-administration, we studied AMPAR and NMDA receptor (NMDAR) binding as well as mGluR1 mRNA expression in mice (Figs. 3,4 ) that underwent cocaineseeking tests on abstinence Days 9 and 43.

A single session of cocaine self-administration induced profound changes in AMPAR and NMDAR binding. Indeed, a widespread decrease in AMPAR binding was observed during early cocaine withdrawal (Day 9; Fig. 4). Thus, cocaine self-administration led to a significant decrease in AMPAR binding in all areas of the prefrontal cortex examined, as well as in the NAc core (NAcC), shell (NAcS), and VTA. In the dorsal hippocampus, bind- ing in the cornus ammon area 3 (CA3) and dentate gyrus (DG) was also significantly reduced by cocaine self-administration. Interestingly, cocaine-induced low AMPAR binding that was observed in the initial phase of abstinence was restored to the level of saline self-administrating mice $35 \mathrm{~d}$ after the last session of self-administration (Day 43; Fig. 4). Following prolonged withdrawal, AMPAR binding levels in the prefrontal cortices (cingulate gyrus, Cg; prelimbic cortex, PrL; and orbitofrontal cortex, OFC) and NAcS were more elevated in cocaine than in saline self-administrating mice. However, the significant cocaineinduced reduction of VTA AMPAR binding was consistent across both withdrawal time points, suggesting differential regulation of AMPAR between these brain regions.

In contrast, cocaine-induced changes in NMDAR availability emerged mostly during prolonged as opposed to early withdrawal (Fig. 4). At Day 9, NMDAR availability in the infralimbic cortex (IL), NAcS, VTA, and basolateral amygdala (BLA) was most affected by cocaine exposure, as seen by a reduction of receptor availability in drug self-administrating mice. After prolonged withdrawal, the central amygdala (CeA), BLA, and dorsal hippocampus (CA1, CA3, and DG) regions exhibited profound downregulation in NMDAR binding, while NMDAR availability returned to the level of controls in the NAcS of cocaine-exposed mice.

In situ hybridization for $m G l u R 1$ mRNA in mice that underwent incubation of cocaine seeking after one session of cocaine self-administration (Fig. 5) revealed significant cocaine-induced changes in $m G l u R 1$ expression during abstinence. A decrease in $m$ GluR 1 expression was observed in the NAcS and VTA in cocaine self-administering mice following both the Day 9 and 43 tests. In contrast, a cocaine-induced increase in $m G l u R 1$ was observed in the prefrontal cortices (PrL and OFC) in both groups. Finally, a cocaine-induced upregulation of $m G l u R 1$ levels emerged after $35 \mathrm{~d}$ of withdrawal in the IL region and hippocampus CA1 and CA3.

\section{Antagonism of mGluR1 enhances cocaine seeking following prolonged abstinence}

To assess the degree of control of mGluR1 signaling on cocaine seeking following prolonged abstinence, we measured cueinduced cocaine seeking in mice that were subjected to one session of cocaine self-administration followed by repeated treatment with the mGluR1 antagonist A-841720. Before treatment with A-841720 or vehicle, mice exhibited similar levels of lever presses during cocaine self-administration (Fig. 6B); a three-way ANOVA showed no main effect of Treatment on lever pressing and no Lever $\times$ Drug $\times$ Treatment $\left(F_{(1,26)}=0.007 ; p=0.932\right)$ or Lever $\times$ Treatment $\left(F_{(1,26)}<0.01 ; p=0.996\right)$ interactions, but a significant Lever $\times$ Drug interaction $\left(F_{(1,26)}=7.51 ; p<0.05\right)$, suggesting increased active lever preference in the cocaine self-administrating groups. The number of infusions earned during the $6 \mathrm{~h}$ session also did not differ between the two cocaine groups, both of which dem- 

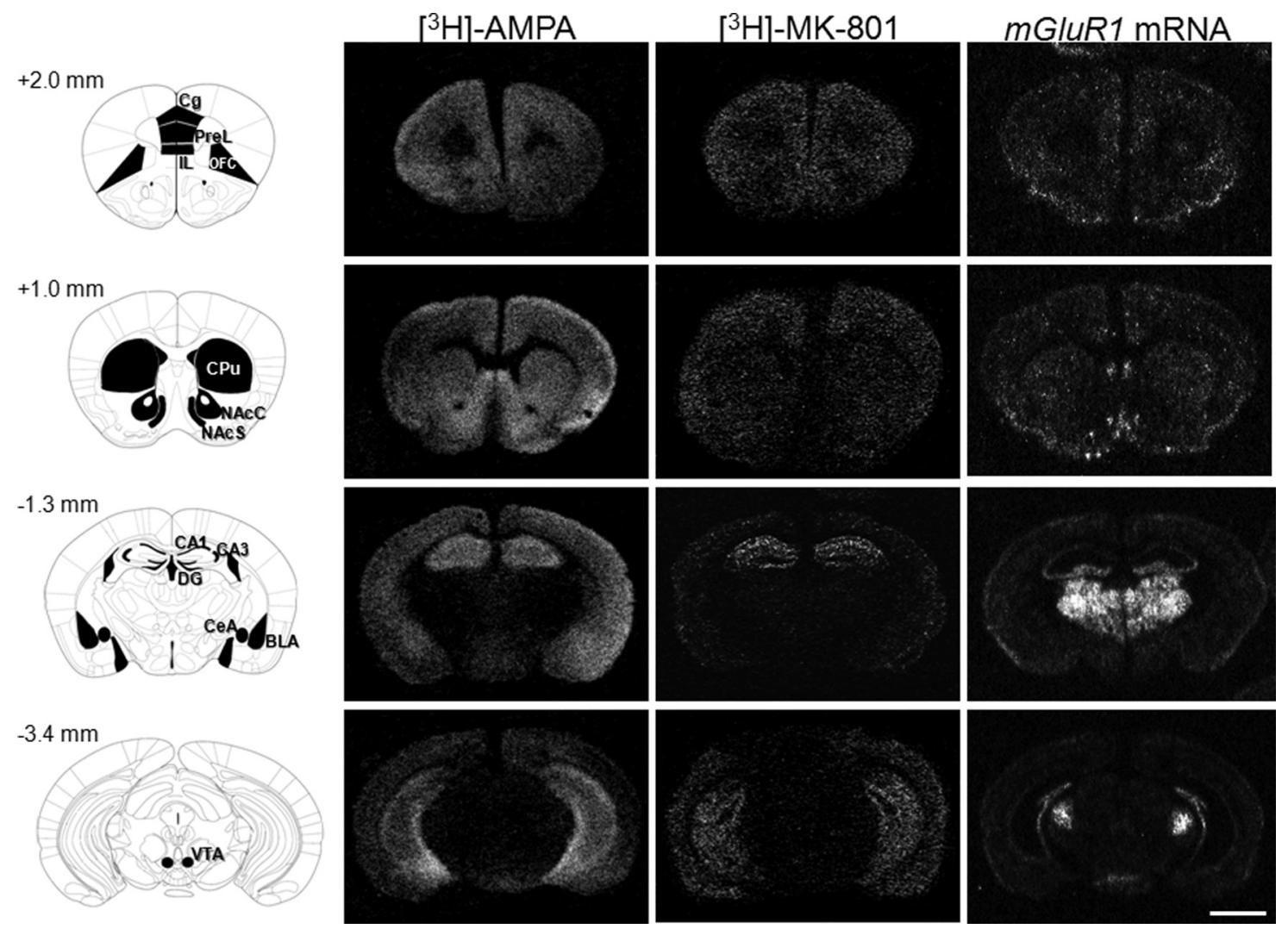

Figure 3. Distribution of AMPAR/NMDAR binding sites and $m G /$ R $1 \mathrm{mRNA}$ in reward-related brain regions. Left, Schematic representation of the areas measured for densitometric evaluation of receptor binding sites and mRNA levels in coronal sections through the mouse forebrain at bregma $+2 \mathrm{~mm},+1 \mathrm{~mm},-1.3 \mathrm{~mm}$, and $-3.4 \mathrm{~mm}$ according to Paxinos and Franklin (2001). Corresponding dark-field microphotographs from autoradiograms of receptor autoradiography for [ $\left.{ }^{3} \mathrm{H}\right]-A M P A$ and $\left[{ }^{3} \mathrm{H}\right]-\mathrm{MK}-801$ and in situ hybridization for $\mathrm{mGluR} 1 \mathrm{mRNA}$ (right) are shown under baseline condition. Scale bar, $2 \mathrm{~mm}$. CPu, caudate-putamen.

onstrated a higher number of infusions than the groups administering saline (Fig. 6C; two-way ANOVA: significant main effect of Drug: $F_{(1,26)}=18.25 ; p<0.001$; but no main effect of Treatment or Drug $\times$ Treatment interaction $p s>0.05$ ). Following the longer duration abstinence (Day 43), cocaine seeking was higher in the group that received treatment with the mGluR1 antagonist, as compared with the vehicle-treated group (Fig. 6D). While an ANOVA revealed only a trend toward a Lever $\times$ Drug $\times$ Treatment interaction $\left(F_{(1,26)}=3.31 ; p=0.08\right)$, post hoc analysis showed that cocaine self-administrating mice demonstrated higher lever pressing following A-841720 treatment as compared to vehicle treatment. The effect of A- 841720 on lever presses was selective to cocaine-associated cues, as there was no treatment effect in saline self-administering mice $(F<1)$. Together these results show that mGluR1 antagonism immediately following cocaine self-administration promotes cocaine seeking following prolonged withdrawal.

\section{Discussion}

Incubation of cocaine seeking is well characterized in rats following prolonged cocaine self-administration, but has not been characterized in mice. We investigated the effect of limited cocaine exposure on drug-seeking in mice, demonstrating for the first time that mice that have self-administered cocaine during either eight sessions, or a single session, both exhibited incubation of cocaine seeking. Interestingly, incubation following a single session of cocaine self-administration was associated with time-dependent changes in AMPAR and NMDAR binding, and $m G l u R 1$ expression. These adaptations in the glutamatergic system suggest that limited exposure to cocaine is sufficient to in- duce long-lasting neuroplasticity in the mesocortical system. Furthermore, our results show that blockade of mGluR1 signaling during early withdrawal enhances cocaine seeking following prolonged abstinence, and supports recent studies demonstrating a key role for mGluR1 in reversing cocaine-induced plasticity associated with the incubation of cocaine seeking at the cellular level (Bellone and Lüscher, 2006; Mameli et al., 2007, 2009; McCutcheon et al., 2011a,b).

Incubation following a single session of cocaine selfadministration is particularly relevant for understanding the initial stages of drug addiction. A single drug exposure may trigger time-dependent behavioral changes that can foster subsequent loss of control over drug intake. A single session of selfadministration in rats promotes drug seeking even after several months of withdrawal (Ciccocioppo et al., 2004), and this behavior is associated with neuroadaptations relevant to the etiology of addiction. Our study complements these findings by demonstrating that cue-induced cocaine seeking is enhanced as a function of time during the first $42 \mathrm{~d}$ of abstinence. Thus, even with limited cocaine exposure and CS-US associations, drug-related memories can be formed and acquire intrinsic motivational properties that enhance drug craving over time. Therefore, the influence of drug-associated cues on drug taking through learning processes such as conditioned reinforcement and pavlovianto-instrumental transfer (Everitt and Robbins, 2005) may also be prone to time-dependent increases that potentiate subsequent drug seeking and drug taking. Because drug-induced plasticity develops following cocaine exposure independently of withdrawal 

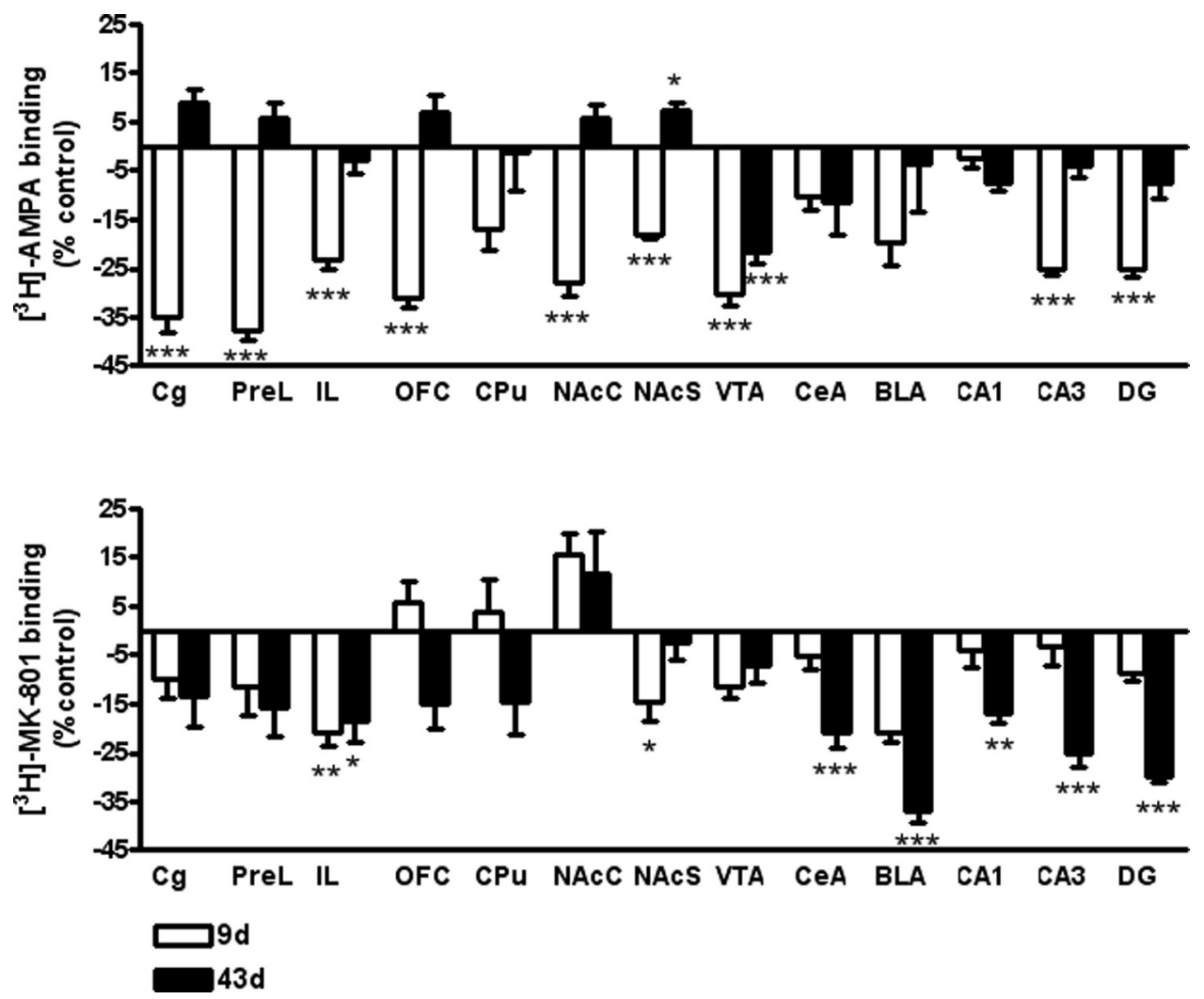

Figure 4. Differential regulation of AMPA and NMDA expression following a single cocaine exposure. Bar graphs illustrate quantitative analysis of [ $\left.{ }^{3} \mathrm{H}\right]-\mathrm{AMPA}$ (top) and [ $\left.{ }^{3} \mathrm{H}\right]-\mathrm{MK}-801$ (NMDA; bottom) binding sites in reward-related forebrain regions of $57 \mathrm{BL} / 6 \mathrm{~N}$ mice $8 \mathrm{~d}$ (white bar) and $42 \mathrm{~d}$ (black bar) after a single cocaine exposure. Data are normalized to respective saline control group (saline group: $100 \%=0$ ) and expressed as mean \pm SEM. Statistical analysis is performed by regionwise two-way ANOVA followed by Fisher's PLSD test and Bonferroni's correction, $n=$ $4-8$ /group, corrected $p$ values: ${ }^{*} p<0.05,{ }^{* *} p<0.01,{ }^{* * *} p<0.001$ versus controls. CPu, caudate-putamen.

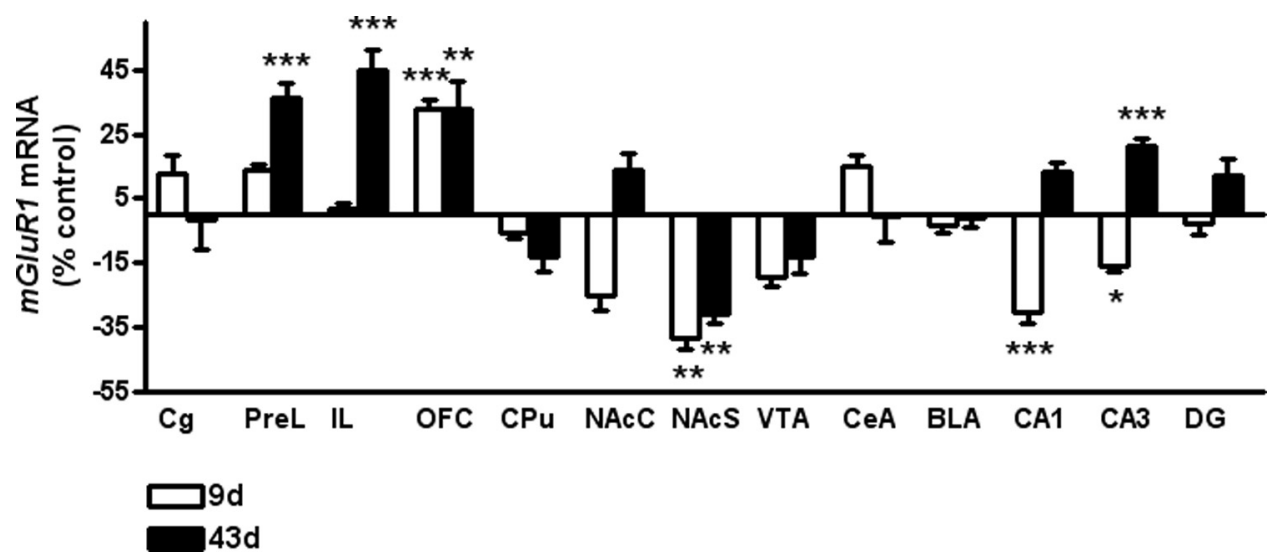

Figure 5. Effects of a single cocaine exposure on $m G l u R 1 \mathrm{mRNA}$ levels following 9 and $43 \mathrm{~d}$. Bar graphs illustrate quantitative analysis of $m G /$ luR $1 \mathrm{mRNA}$ levels $8 \mathrm{~d}$ (white bar) and $42 \mathrm{~d}$ (dark bar) after a single exposure of cocaine in reward-related forebrain regions of $(57 \mathrm{BL} / 6 \mathrm{~N}$ mice. Data are normalized to the respective saline control group (saline group: $100 \%=0$ ) and expressed as mean \pm SEM. Statistical analysis is performed by regionwise two-way ANOVA followed by Fisher's PLSD test and Bonferroni's correction, $n=4-8 /$ group, corrected $p$ values: ${ }^{*} p<0.05$, ${ }^{* *} p<$ $0.01,{ }^{* * *} p<0.001$ versus controls. CPu, caudate-putamen.

(Dobi et al., 2011), we hypothesize that a single drug experience might have a dramatic influence on subsequent drug intake by potentiating the control that drug-associated cues have on drug use, and consequently promoting the escalation of cocaine taking (Ahmed and Koob, 1998; but see Jonkman et al., 2012).

The role of AMPARs in incubation of cocaine seeking Consistent with observations that time-dependent adaptations in glutamate transmission in the VTA and NAc (Pickens et al., 2011; Wolf and Tseng, 2012) and glutamate activation in the CeA (Lu et al., 2005a,b, 2007) play a critical role in the development of incubation of cocaine seeking, our study uncovers significant changes following limited cocaine experience in AMPAR and NMDAR binding in most brain regions associated with reward processing. Changes in glutamatergic transmission during cocaine withdrawal involve modifications in AMPAR and NMDAR subunit composition or receptor subcellular localization that cannot be distinguished using binding studies. Nonetheless, we speculate that time-dependent changes in receptor availability reflect regional changes in neuronal excitability. AMPAR binding was 
A

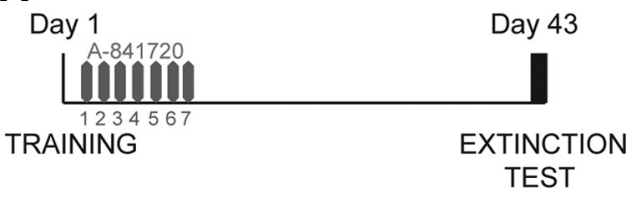

B

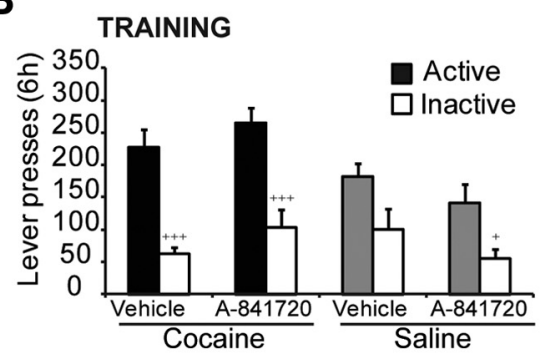

C

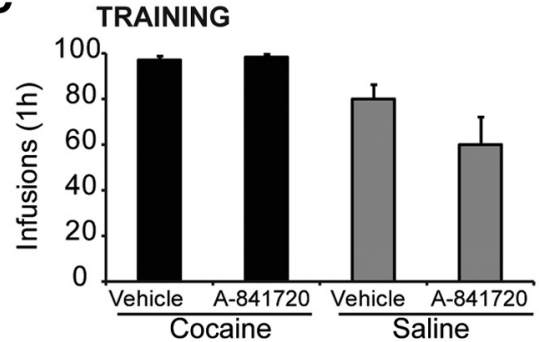

D

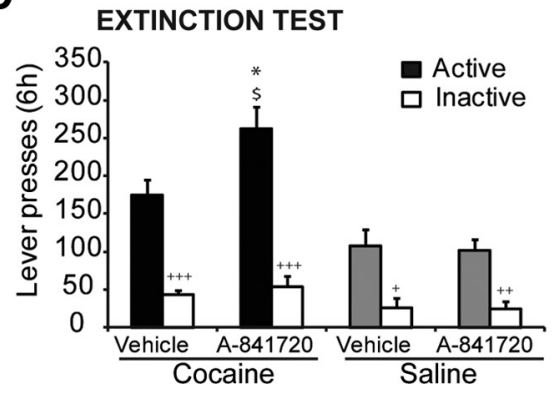

Figure 6. The mGluR1 antagonist A-841720 enhances cocaine seeking following prolonged withdrawal. $A$, Schematic diagram of the experimental procedure. Cocaine self-administration on Day 1 (TRAINING) is followed by seven repeated injections of A-841720 or vehicle. Cueinduced drug seeking was measured on Day 43 (EXTINCTION TEST). $\boldsymbol{B}$, The number of lever presses for cocaine self-administration is similar in mice subsequently treated with $A-841720$ or vehicle $\left({ }^{+} p<0.05,{ }^{+++} p<0.001\right.$ vs Active). C, Similar cocaine self-administration experience (number of infusions) in mice before treatment with $A-841720 . D$, The number of active lever presses during cue-induced cocaine seeking is significantly increased in mice treated with the mGluR1 antagonist A-841720 but unchanged in saline self-administrating mice $\left({ }^{*} p<0.05\right.$ vs Vehicle treated; ${ }^{\$} p<0.05$ vs Saline; ${ }^{+} p<0.05,{ }^{++} p<0.01$ and ${ }^{+++} p<0.001$ vs Active). Data are expressed as mean \pm SEM.

strongly reduced during early withdrawal from a single session of cocaine self-administration in most brain areas examined, suggesting that early homeostatic regulations take place following limited cocaine exposure. While the functional relevance of AMPAR availability in cue-induced cocaine seeking still remains to be determined, the widespread decrease in AMPAR binding may result in the suppression of cue-maintained responding during early withdrawal as a result of lower excitability of regions such as the NAc. However, changes in the glutamate system following protracted cocaine withdrawal suggest that the incubation of cocaine seeking is also mediated by the time-sensitive onset of neuronal modifications. Conrad et al. (2008) demonstrated that increased NAc medium spiny neuron (MSN) excitability during withdrawal mediates time-dependent increases in cocaine seeking via the specific incorporation of CP-AMPAR. During early withdrawal, we observed in the NAcC and NAcS significantly lower levels of AMPAR in mice that self-administered cocaine, as compared to saline. This cocaine-induced AMPAR downregulation was inverted during late withdrawal; on Day 43 we observed significantly higher levels of AMPAR in the cocaine group. It is likely that increased excitability of MSNs in the NAc during withdrawal results both from changes in the intrinsic physiological properties of AMPAR incorporation (CP- vs CI-AMPAR) and the availability of total receptors in this region.

Several studies have shown that cocaine exposure strengthens VTA excitatory synapses (Wolf and Tseng, 2012), and this phenomenon persists during withdrawal and involves the synaptic insertion of CP-AMPAR when drug intake is both contingent (Chen et al., 2008; Mameli et al., 2009) and noncontingent (Argilli et al., 2008; Chen et al., 2008; but see Choi et al., 2011). Here, the availability of total AMPAR was downregulated in the VTA during early and late withdrawal following a single session of cocaine self-administration, suggesting that limited cocaine selfadministration induces persistent adaptive mechanisms in VTA excitatory transmission, and that CP-AMPAR synaptic insertion may occur in distinct localizations (Lane et al., 2010, 2011), in contrast to a "background" downregulation of AMPAR. Further investigations will reveal whether VTA AMPAR downregulation also takes place following extended cocaine self-administration, and whether this phenomenon increases the importance of synapses that undergo CP-AMPAR-mediated strengthening of excitatory inputs.

\section{The role of NMDARs in incubation of cocaine seeking}

As previously shown in rats (Ben-Shahar et al., 2007), our study demonstrates that limited cocaine exposure leads to lower availability of NMDAR in the IL during early withdrawal. Our data suggest, however, that prefrontal cocaine-induced decreases in NMDAR availability may persist over $42 \mathrm{~d}$ of abstinence, which together with upregulation of $m G l u R 1$ may contribute to altered functionality of frontal cortical areas associated with addiction (Jentsch and Taylor, 1999; Kalivas and Volkow, 2005). Following extended cocaine self-administration, changes in neuronal activity of the ventral prefrontal cortex have been shown to play a regulatory role in the expression of cocaine incubation (Koya et al., 2009). These structures provide important excitatory projections to the NAcS (Voorn et al., 2004), and may orchestrate changes in glutamate receptors level observed in the ventral striatum.

Interestingly, a single session of cocaine self-administration significantly downregulated NMDAR expression in several subregions of the amygdala and dorsal hippocampus following both short and long withdrawal durations. The role of the amygdala in reward-associated learning is well established (Buffalari and See, 2010). ERK activation in the CeA is critical for the expression of incubation of cocaine seeking and depends upon glutamate signaling on NMDAR (Lu et al., 2005a,b, 2007). Moreover, the hippocampus, via its connectivity with the NAc and the VTA, has been shown to be instrumental in cocaine seeking (Vorel et al., 2001) and reward-associated learning (Luo et al., 2011). As the exact nature of hippocampal and amygdala neuroadaptations that influence incubation has yet to be defined, our data suggest the potential role of changes in NMDAR and mGluR1 levels. 


\section{The role of mGluR1 in incubation of cocaine seeking}

Signaling through mGluR1 is key to the regulation of neuroplasticity events that mediate the incubation of cocaine seeking. We have shown that incubation following limited cocaine exposure is associated with pronounced changes in mGluR1 levels in frontal cortical regions, the ventral striatum and dorsal hippocampus. In the NAcS, $m$ GluR1 levels were considerably downregulated during both early and late withdrawal. As cocaine-induced plasticity can be reverted via the activation of mGluR1 in the NAc (McCutcheon et al., 2011b), our results indicate that even limited cocaine exposure may disrupt this protective mechanism by altering the transcription of $m G l u R 1$. Although changes in mRNA levels do not necessarily reflect changes in protein levels and function, similar variations in mGluR1 protein levels have previously been described following both contingent (Ben-Shahar et al., 2013) and noncontingent exposure to cocaine (Ary and Szumlinski, 2007). Furthermore, in support of the hypothesis that impaired mGluR1 function increases the vulnerability to cocaine seeking, we have shown that blockade of mGluR1 signaling with repeated injections of an mGluR1 antagonist following self-administration potentiated cue-induced cocaine seeking after prolonged withdrawal. This finding provides a behavioral correlate to the electrophysiological findings of Mameli et al. (2009), who demonstrated that a single exposure to cocaine in mice, followed by administration of the mGluR1 antagonist AIDA, produced changes in cocaine-induced plasticity similar to repeated cocaine treatment, again suggesting that impaired mGluR1 function may represent a gating mechanism responsible for higher vulnerability to neuroadaptations associated with drug dependence.

\section{Conclusion}

Our results show that a single session of cocaine selfadministration is sufficient to induce neuroplastic adaptations, likely involving glutamate transmission, that enable neutral cues to become powerful incentives, increasing the risk of drug seeking even after protracted withdrawal. Furthermore, consistent with previous reports that mGluR1 signaling controls cocaineinduced plasticity, our results suggest that impaired glutamate signaling through mGluR1 may increase the long-lasting vulnerability to drug-associated memories. As incubation may translate to the human condition, occurring even as baseline craving ratings decline (Bedi et al., 2011), our results suggest potentially important clinical implications, namely that a single drug exposure may render an individual vulnerable to an augmented risk of cocaine seeking for a prolonged period, perhaps serving as a gateway to a chronic abuse pattern.

\section{References}

Ahmed SH, Koob GF (1998) Transition from moderate to excessive drug intake: change in hedonic set point. Science 282:298-300. CrossRef Medline

Argilli E, Sibley DR, Malenka RC, England PM, Bonci A (2008) Mechanism and time course of cocaine-induced long-term potentiation in the ventral tegmental area. J Neurosci 28:9092-9100. CrossRef Medline

Ary AW, Szumlinski KK (2007) Regional differences in the effects of withdrawal from repeated cocaine upon Homer and glutamate receptor expression: a two-species comparison. Brain Res 1184:295-305. CrossRef Medline

Bedi G, Preston KL, Epstein DH, Heishman SJ, Marrone GF, Shaham Y, de Wit H (2011) Incubation of cue-induced cigarette craving during abstinence in human smokers. Biol Psychiatry 69:708-711. CrossRef Medline

Bellone C, Lüscher C (2006) Cocaine triggered AMPA receptor redistribution is reversed in vivo by mGluR-dependent long-term depression. Nat Neurosci 9:636-641. CrossRef Medline
Ben-Shahar O, Keeley P, Cook M, Brake W, Joyce M, Nyffeler M, Heston R, Ettenberg A (2007) Changes in levels of D1, D2, or NMDA receptors during withdrawal from brief or extended daily access to IV cocaine. Brain Res 1131:220-228. CrossRef Medline

Ben-Shahar O, Sacramento AD, Miller BW, Webb SM, Wroten MG, Silva HE, Caruana AL, Gordon EJ, Ploense KL, Ditzhazy J, Kippin TE, Szumlinski KK (2013) Deficits in ventromedial prefrontal cortex group 1 metabotropic glutamate receptor function mediate resistance to extinction during protracted withdrawal from an extensive history of cocaine selfadministration. J Neurosci 33:495-506a. CrossRef Medline

Boudreau AC, Wolf ME (2005) Behavioral sensitization to cocaine is associated with increased AMPA receptor surface expression in the nucleus accumbens. J Neurosci 25:9144-9151. CrossRef Medline

Buffalari DM, See RE (2010) Amygdala mechanisms of Pavlovian psychostimulant conditioning and relapse. Curr Top Behav Neurosci 3:73-99. CrossRef Medline

Chen BT, Bowers MS, Martin M, Hopf FW, Guillory AM, Carelli RM, Chou JK, Bonci A (2008) Cocaine but not natural reward self-administration nor passive cocaine infusion produces persistent LTP in the VTA. Neuron 59:288-297. CrossRef Medline

Choi KH, Edwards S, Graham DL, Larson EB, Whisler KN, Simmons D, Friedman AK, Walsh JJ, Rahman Z, Monteggia LM, Eisch AJ, Neve RL, Nestler EJ, Han MH, Self DW (2011) Reinforcement-related regulation of AMPA glutamate receptor subunits in the ventral tegmental area enhances motivation for cocaine. J Neurosci 31:7927-7937. CrossRef Medline

Ciccocioppo R, Martin-Fardon R, Weiss F (2004) Stimuli associated with a single cocaine experience elicit long-lasting cocaine-seeking. Nat Neurosci 7:495-496. CrossRef Medline

Conrad KL, Tseng KY, Uejima JL, Reimers JM, Heng LJ, Shaham Y, Marinelli M, Wolf ME (2008) Formation of accumbens GluR2-lacking AMPA receptors mediates incubation of cocaine craving. Nature 454:118-121. CrossRef Medline

Dobi A, Seabold GK, Christensen CH, Bock R, Alvarez VA (2011) Cocaineinduced plasticity in the nucleus accumbens is cell specific and develops without prolonged withdrawal. J Neurosci 31:1895-1904. CrossRef Medline

Ehrman RN, Robbins SJ, Childress AR, O’Brien CP (1992) Conditioned responses to cocaine-related stimuli in cocaine abuse patients. Psychopharmacology 107:523-529. CrossRef Medline

El-Kouhen O, Lehto SG, Pan JB, Chang R, Baker SJ, Zhong C, Hollingsworth PR, Mikusa JP, Cronin EA, Chu KL, McGaraughty SP, Uchic ME, Miller LN, Rodell NM, Patel M, Bhatia P, Mezler M, Kolasa T, Zheng GZ, Fox GB, et al. (2006) Blockade of mGluR1 receptor results in analgesia and disruption of motor and cognitive performances: effects of A-841720, a novel non-competitive mGluR1 receptor antagonist. Br J Pharmacol 149: 761-774. CrossRef Medline

Epstein DH, Preston KL, Stewart J, Shaham Y (2006) Toward a model of drug relapse: an assessment of the validity of the reinstatement procedure. Psychopharmacology 189:1-16. CrossRef Medline

Everitt BJ, Robbins TW (2005) Neural systems of reinforcement for drug addiction: from actions to habits to compulsion. Nat Neurosci 8:14811489. CrossRef Medline

Gawin FH (1991) Cocaine addiction: psychology and neurophysiology. Science 251:1580-1586. CrossRef Medline

Gawin FH, Kleber HD (1986) Abstinence symptomatology and psychiatric diagnosis in cocaine abusers. Arch Gen Psychiatry 43:107-113. CrossRef Medline

Grimm JW, Hope BT, Wise RA, Shaham Y (2001) Neuroadaptation. Incubation of cocaine craving after withdrawal. Nature 412:141-142. CrossRef Medline

Hansson AC, Cippitelli A, Sommer WH, Fedeli A, Björk K, Soverchia L, Terasmaa A, Massi M, Heilig M, Ciccocioppo R (2006) Variation at the rat Crhr1 locus and sensitivity to relapse into alcohol seeking induced by environmental stress. Proc Natl Acad Sci US A 103:15236-15241. CrossRef Medline

Hansson AC, Rimondini R, Neznanova O, Sommer WH, Heilig M (2008) Neuroplasticity in brain reward circuitry following a history of ethanol dependence. Eur J Neurosci 27:1912-1922. CrossRef Medline

Hollander JA, Carelli RM (2007) Cocaine-associated stimuli increase cocaine seeking and activate accumbens core neurons after abstinence. J Neurosci 27:3535-3539. CrossRef Medline 
Hyman SE, Malenka RC, Nestler EJ (2006) Neural mechanisms of addiction: the role of reward-related learning and memory. Annu Rev Neurosci 29:565-598. CrossRef Medline

Jentsch JD, Taylor JR (1999) Impulsivity resulting from frontostriatal dysfunction in drug abuse: implications for the control of behavior by reward-related stimuli. Psychopharmacology 146:373-390. CrossRef Medline

Jonkman S, Pelloux Y, Everitt BJ (2012) Drug intake is sufficient, but conditioning is not necessary for the emergence of compulsive cocaine seeking after extended self-administration. Neuropsychopharmacology 37: 1612-1619. CrossRef Medline

Kalivas PW, Volkow ND (2005) The neural basis of addiction: a pathology of motivation and choice. Am J Psychiatry 162:1403-1413. CrossRef Medline

Koya E, Uejima JL, Wihbey KA, Bossert JM, Hope BT, Shaham Y (2009) Role of ventral medial prefrontal cortex in incubation of cocaine craving. Neuropharmacology 56 [Suppl 1]:177-185. CrossRef Medline

Lane DA, Jaferi A, Kreek MJ, Pickel VM (2010) Acute and chronic cocaine differentially alter the subcellular distribution of AMPA GluR1 subunits in region-specific neurons within the mouse ventral tegmental area. Neuroscience 169:559-573. CrossRef Medline

Lane DA, Reed B, Kreek MJ, Pickel VM (2011) Differential glutamate AMPA-receptor plasticity in subpopulations of VTA neurons in the presence or absence of residual cocaine: implications for the development of addiction. Neuropharmacology 61:1129-1140. CrossRef Medline

Li X, DeJoseph MR, Urban JH, Bahi A, Dreyer JL, Meredith GE, Ford KA, Ferrario CR, Loweth JA, Wolf ME (2013) Different roles of BDNF in nucleus accumbens core versus shell during the incubation of cueinduced cocaine craving and its long-term maintenance. J Neurosci 33: 1130-1142. CrossRef Medline

Lu L, Grimm JW, Hope BT, Shaham Y (2004) Incubation of cocaine craving after withdrawal: a review of preclinical data. Neuropharmacology 47 [Suppl 1]:214-226. Medline

Lu L, Dempsey J, Shaham Y, Hope BT (2005a) Differential long-term neuroadaptations of glutamate receptors in the basolateral and central amygdala after withdrawal from cocaine self-administration in rats. J Neurochem 94:161-168. CrossRef Medline

Lu L, Hope BT, Dempsey J, Liu SY, Bossert JM, Shaham Y (2005b) Central amygdala ERK signaling pathway is critical to incubation of cocaine craving. Nat Neurosci 8:212-219. CrossRef Medline

Lu L, Uejima JL, Gray SM, Bossert JM, Shaham Y (2007) Systemic and central amygdala injections of the mGluR(2/3) agonist LY379268 attenuate the expression of incubation of cocaine craving. Biol Psychiatry 61:591598. CrossRef Medline

Lu L, Wang X, Wu P, Xu C, Zhao M, Morales M, Harvey BK, Hoffer BJ, Shaham Y (2009) Role of ventral tegmental area glial cell line-derived neurotrophic factor in incubation of cocaine craving. Biol Psychiatry 66: 137-145. CrossRef Medline

Luo AH, Tahsili-Fahadan P, Wise RA, Lupica CR, Aston-Jones G (2011) Linking context with reward: a functional circuit from hippocampal CA3 to ventral tegmental area. Science 333:353-357. CrossRef Medline

Lüscher C, Malenka RC (2011) Drug-evoked synaptic plasticity in addiction: from molecular changes to circuit remodeling. Neuron 69:650-663. CrossRef Medline

Mameli M, Balland B, Luján R, Lüscher C (2007) Rapid synthesis and synaptic insertion of GluR2 for mGluR-LTD in the ventral tegmental area. Science 317:530-533. CrossRef Medline
Mameli M, Halbout B, Creton C, Engblom D, Parkitna JR, Spanagel R, Lüscher C (2009) Cocaine-evoked synaptic plasticity: persistence in the VTA triggers adaptations in the NAc. Nat Neurosci 12:1036-1041. CrossRef Medline

McCutcheon JE, Wang X, Tseng KY, Wolf ME, Marinelli M (2011a) Calcium-permeable AMPA receptors are present in nucleus accumbens synapses after prolonged withdrawal from cocaine self-administration but not experimenter-administered cocaine. J Neurosci 31:5737-5743. CrossRef Medline

McCutcheon JE, Loweth JA, Ford KA, Marinelli M, Wolf ME, Tseng KY (2011b) Group I mGluR activation reverses cocaine-induced accumulation of calcium-permeable AMPA receptors in nucleus accumbens synapses via a protein kinase C-dependent mechanism. J Neurosci 31:1453614541. CrossRef Medline

Mead AN, Zamanillo D, Becker N, Stephens DN (2007) AMPA-receptor GluR1 subunits are involved in the control over behavior by cocainepaired cues. Neuropsychopharmacology 32:343-353. CrossRef Medline

Meil WM, See RE (1996) Conditioned cued recovery of responding following prolonged withdrawal from self-administered cocaine in rats: an animal model of relapse. Behav Pharmacol 7:754-763. Medline

Noori HR, Spanagel R, Hansson AC (2012) Neurocircuitry for modeling drug effects. Addict Biol 17:827-864. CrossRef Medline

O’Brien CP (1997) A range of research-based pharmacotherapies for addiction. Science 278:66-70. CrossRef Medline

Paxinos G, Franklin KBJ (2001) The mouse brain in stereotaxic coordinates, Ed 2. San Diego, CA: Academic.

Pickens CL, Airavaara M, Theberge F, Fanous S, Hope BT, Shaham Y (2011) Neurobiology of the incubation of drug craving. Trends Neurosci 34:411420. CrossRef Medline

Sanchis-Segura C, Spanagel R (2006) Behavioural assessment of drug reinforcement and addictive features in rodents: an overview. Addict Biol 11:2-38. CrossRef Medline

Spanagel R, Bartsch D, Brors B, Dahmen N, Deussing J, Eils R, Ende G, Gallinat J, Gebicke-Haerter P, Heinz A, Kiefer F, Jäger W, Mann K, Matthäus F, Nöthen M, Rietschel M, Sartorius A, Schütz G, Sommer WH, Sprengel R, et al. (2010) An integrated genome research network for studying the genetics of alcohol addiction. Addict Biol 15:369-379. CrossRef Medline

Stephens DN, Duka T, Crombag HS, Cunningham CL, Heilig M, Crabbe JC (2010) Reward sensitivity: issues of measurement, and achieving consilience between human and animal phenotypes. Addict Biol 15:145-168. CrossRef Medline

Thiel KJ, Painter MR, Pentkowski NS, Mitroi D, Crawford CA, Neisewander JL (2012) Environmental enrichment counters cocaine abstinenceinduced stress and brain reactivity to cocaine cues but fails to prevent the incubation effect. Addict Biol 17:365-377. CrossRef Medline

Voorn P, Vanderschuren LJ, Groenewegen HJ, Robbins TW, Pennartz CM (2004) Putting a spin on the dorsal-ventral divide of the striatum. Trends Neurosci 27:468-474. CrossRef Medline

Vorel SR, Liu X, Hayes RJ, Spector JA, Gardner EL (2001) Relapse to cocaine-seeking after hippocampal theta burst stimulation. Science 292: 1175-1178. CrossRef Medline

Wolf ME, Tseng KY (2012) Calcium-permeable AMPA receptors in the VTA and nucleus accumbens after cocaine exposure: when, how, and why? Front Mol Neurosci 5:72. Medline 